\title{
KINH NGHIỆM PHẪU THUẬT CÁC KHỐI U TRUNG THÂT LỚN TẠI BỆNH VIỆN BẠCH MAI
}

Ngô Gia Khánh*, Mạc Thế Truờng*, Đặng Thị Hoa*

\section{TÓM TÁT:}

Từ tháng 3/2017 đến tháng 3/2019, khoa Phẫu thuật Lồng ngực - Bệnh viện Bạch Mai đã phẫu thuật thành công cho 20 trường hợp có khối u trung thất lớn hơn $10 \mathrm{~cm}$, không có bệnh nhân tử vong, không có biến chứng nặng trong và sau mổ. Tiên lượng chính xác khả năng cắt $\mathrm{u}$, có kế hoạch điều trị rõ ràng, lựa chọn hướng tiếp cận đúng. Kinh nghiệm của phẫu thuật viên và đội ngũ gây mê cũng như sự phối hợp tốt giữa các chuyên nghành là yếu tố làm nên thành công của quá trình điều trị các khối u trung thất lớn

Tù khóa: U trung thất, phẫu thuật lồng ngụcc

\section{LARGE MEDIASTINAL MASS RESECTION: EXPERIENCES FROM BACH MAI HOSPITAL}

From March 2018 to March 2019, we performed on 20 patients.There was no inhospital mortality or major postoperative complication. Preoperative preparation measures include appropriate preoperative multimodality imaging, with emphasis on the vascular anatomy of the tumor. With adequate preoperative team planning, a safe anesthesiological and surgical strategy can be accomplished.

Key words: mediastinal tumor, thoracic surgery

\section{I. Đạ̄T VÁN ĐỀ}

U trung thất lớn là bệnh lý hiếm gặp, bao gồm cả các khối u lành tính và ác tính [1]. Các khối u trung thất lớn, đặt biệt các khối u gây chèn ép hoặc xâm lấn các cấu trúc xung quanh và giải phẫu phức tạp của trung thất đặt ra những thách thức lớn cho các phẫu thuật viên trong việc cắt bỏ khối u. Ngoài ra, khối u trung thất lớn cũng gây ra nhiều thách thức cho các bác sĩ gây mê do suy hô hấp hoặc rối loạn huyết động mất bù [2]. Do đó, việc chuẩn bị chi tiết trước phẫu thuật, hội chẩn đa chuyên ngành và sự phối hợp chặt chẽ giữa phẫu thuật viên và bác sĩ gây mê là những điều kiện cần thiết cho kết quả phẫu thuật tốt.

\section{MÔ TẢ CA LÂM SÀNG}

Trong điều kiện bài viết, chúng tôi chỉ mô tả các ca lâm sàng để minh họa cho phần bàn luận.

Ca 1: Bệnh nhân nam, 28 tuổi, vào viện vì khó thở và đau ngực. CLVT ngực có khối u trung thất trước kích thước $12 \times 9 \mathrm{~cm}$. Bệnh nhân được mở ngực đường giữa xương ức, cắt toàn bộ khối u. Giải phẫu bệnh sau mổ là u quái thành thục.

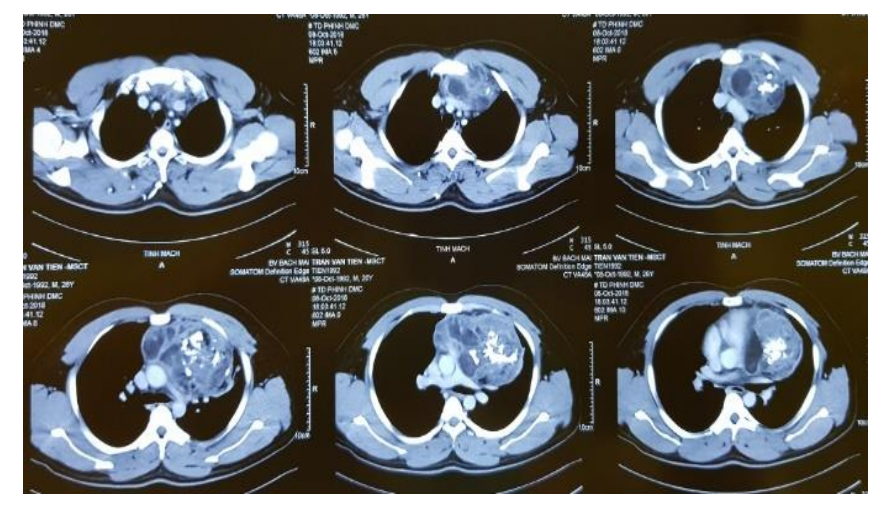

* Bệnh viện Bạch Mai

Người chịu trách nhiệm khoa học: BS Ngô Gia Khánh

Ngày nhận bài: 01/11/2019 - Ngày Cho Phép Đăng: 20/12/2019

Phản Biện Khoa học: PGS.TS. Đặng Ngọc Hùng GS.TS. Lê Ngoc Thành 

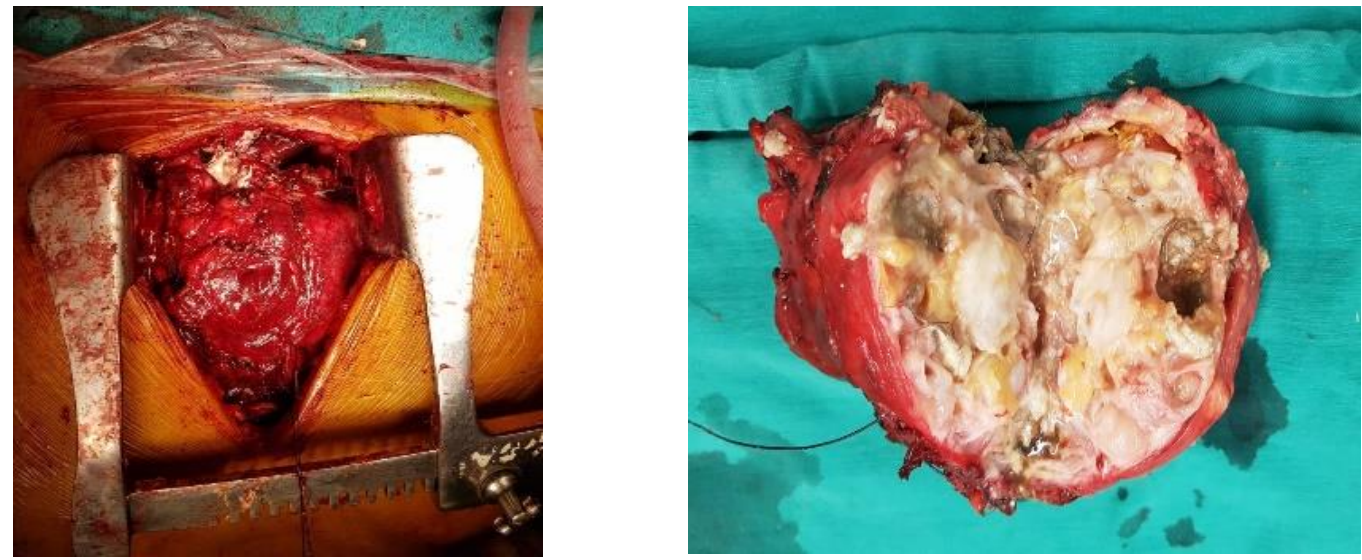

Ca 2: Bệnh nhân nữ, 56 tuổi, vào viện vì nhược cơ và đau vai gáy. CLVT ngực có khối u trung thất kích thước $6,5 \times 11 \mathrm{~cm}$ xâm lấn tĩnh mạch chủ trên, u thùy giữa phổi phải kích thước $2 \times 3 \mathrm{~cm}$. Bệnh nhân được mở ngực đường Hemi-clamshell, đánh giá trong mổ u trung thất lớn xâm lấn màng tim, màng phổi, tĩnh mạch chủ trên, tĩnh mạch vô danh và thùy giữa phổi phải. Bệnh nhân đã được cắt toàn bộ khối $\mathrm{u}$, tạo hình lại hệ tĩnh mạch chủ trên, tĩnh mạch vô danh bằng miếng vá sinh học, cắt thùy giữa phổi phải. Giải phẫu bệnh sau mổ là u tuyến ức typ $\mathrm{AB}$.

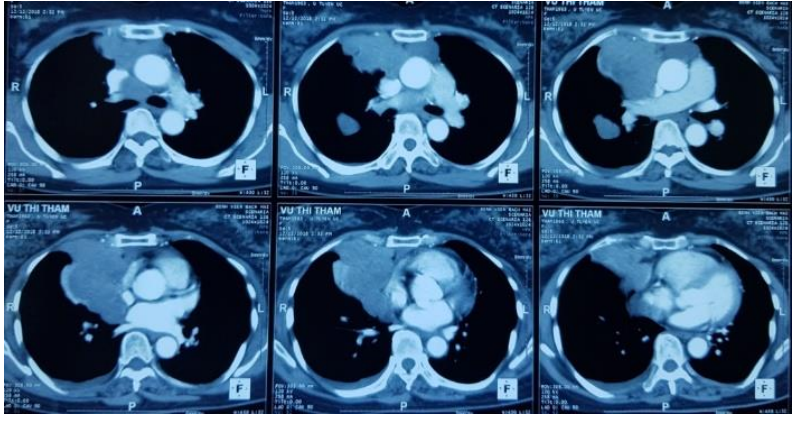

Khối u trung thất lớn xâm lấn tĩnh mạch chủ trên

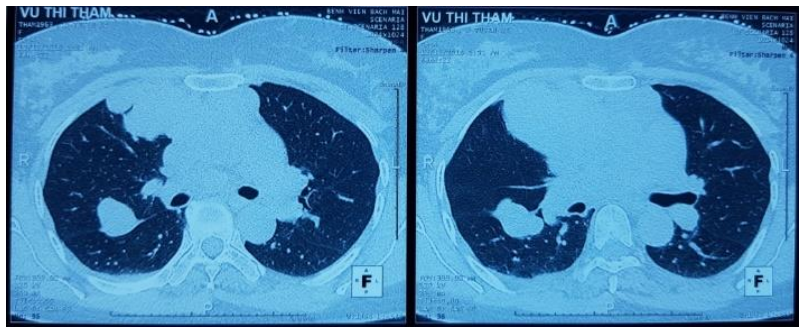

Khối u xâm lấn thùy giữa phổi phải
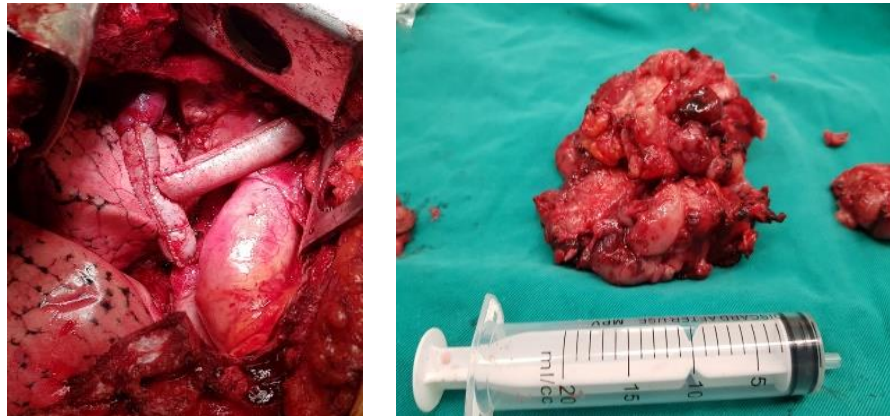

Khôi u cắt ra và tĩnh mạch chủ trên, tĩnh mạch vô danh được tạo hình lại bằng miếng vá sinh học

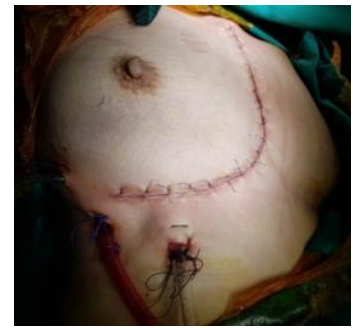

Đường mở ngục Hemi-clamshell

Ca 3: Bệnh nhân nam, 49 tuổi, vào viện vì khó thở, mệt mỏi, sút cân, thiếu máu nặng. Công thức máu lúc vào viện hồng cầu 2,56 G/l, hematocrit 0,153 . CLVT ngực có khối u lớn chiếm toàn bộ ngực phải. Bệnh nhân được mở ngực đường trước - bên, đánh giá trong mổ khối u chiếm toàn bộ ngực phải, vỏ dày, chèn ép gây xẹp phổi phải hoàn toàn, bóp bóng không nở được. Bệnh nhân được mổ cắt toàn bộ u trung thất và phổi phải. Giải phẫu bệnh sau mổ là u mạch bạch huyết lành tính. 

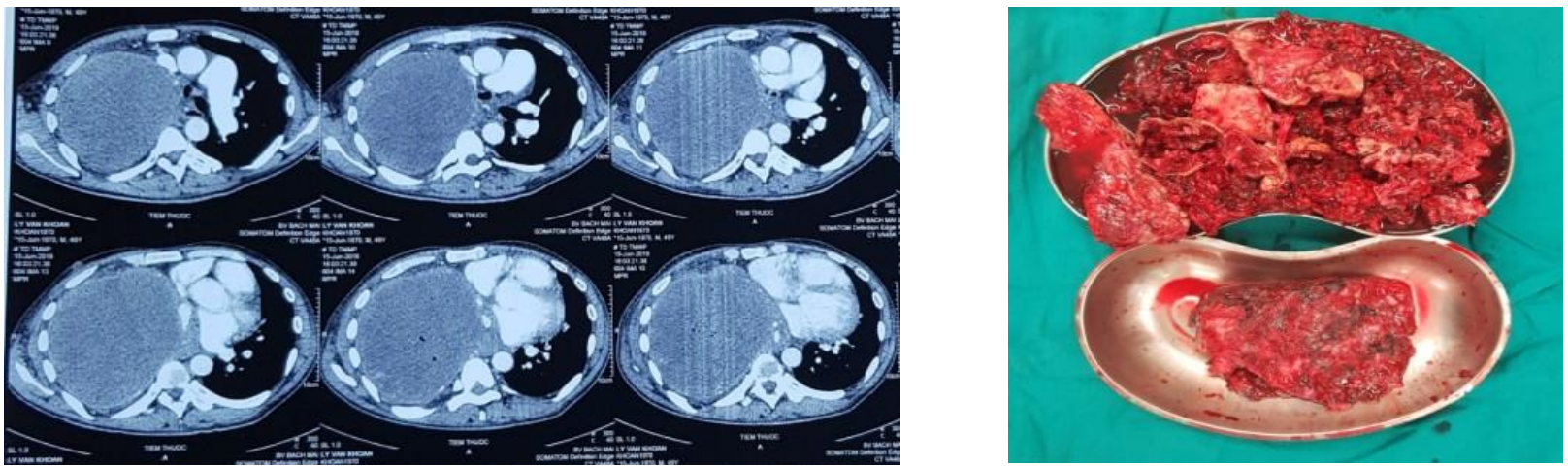

Ca 4: Bệnh nhân nam, 39 tuổi, vào viện vì tê bì và yếu chân phải. Phim cộng hưởng từ có hình ảnh khối u trung thất sau kích thước $5 \times 10 \mathrm{~cm}$ lan vào ống sống. Bệnh nhân đã được mổ phối hợp với chuyên khoa Chấn thương chỉnh hình và cột sống (mở cung sau lấy u, cố định cột sống) kèm tho mở ngực đường sau bên cắt $\mathrm{u}$. Giải phẫu bệnh sau mổ là $\mathrm{u}$ xơ thần kinh lành tính.
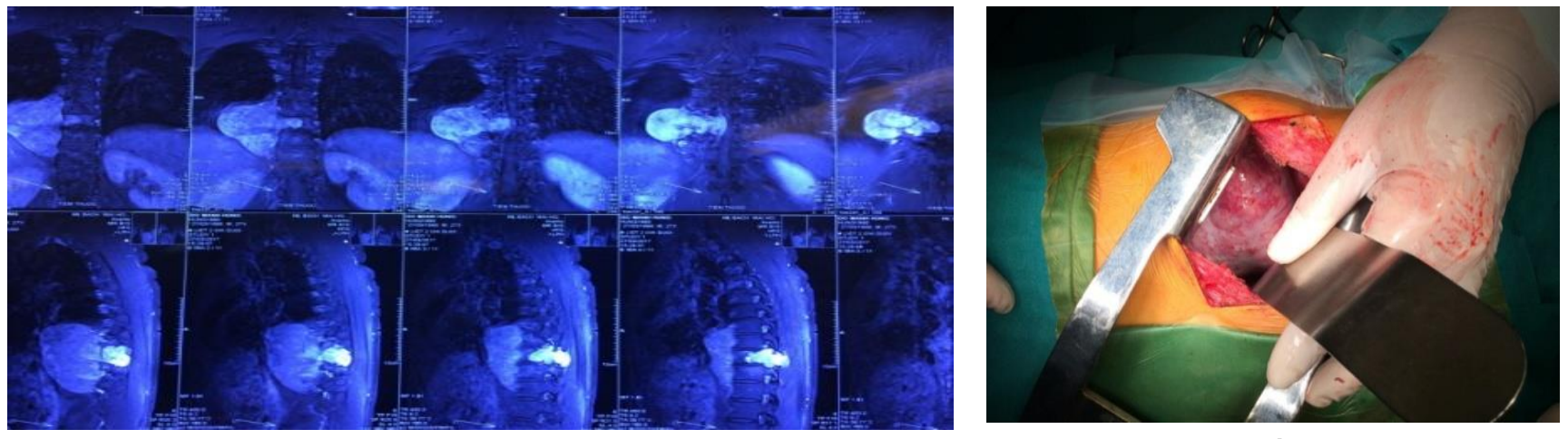

III. BÀN LUẦN

\subsection{Chuẩn bị bệnh nhân trước mổ}

Đánh giá chính xác hình thái khối u, vị trí giải phẫu, mối quan hệ của khối với các cấu trúc xung quanh, đặc biệt các mạch máu lớn và cây khí phế quản là những thông tin rất cần thiết cho gây mê và phẫu thuật. Nên sử dụng chụp CLVT độ phân giải cao và có tiêm thuốc để đánh giá mạch máu khối u và vùng lân cận [3]. Chụp cộng hưởng từ có thể được chỉ định giúp đánh giá chính xác hơn sự xâm lấn trung thất và thành ngực của khối u khi so sánh với CLVT hay với các khối $\mathrm{u}$ trung thất sau nằm sát cột sống [4]. Siêu âm tim, nội soi phế quản, đo chức năng hô hấp cung cấp những thông tin quan trọng cho quá trình gây mê.

\subsection{Giảm kích thước khối u trước mổ}

Tùy thuộc vào chẩn đoán mô bệnh học, hóa xạ trị trước mổ có thể đóng vai trò quan trọng trong việc giảm kích thước khối u và tạo thuận lợi cho quá trình phẫu thuật [5]. Ví dụ: đối với khối u tế bào mầm nên hóa trị trước sau đó phẫu thuật cắt bỏ khối u còn lại; trong $\mathrm{u}$ tuyến ức một số nghiên cứu cho thấy hóa xạ trị đạt được thành công trong việc giảm kích thước khối u [6]. Ngoài ra, nút mạch trước phẫu thuật với những khối u lớn, tăng sinh mạch nhiều có thể làm giảm biến chứng chảy máu trong mổ. Tuy nhiên kỹ thuật này có làm giảm được kích thước $\mathrm{u}$ hay không thì vẫn còn nhiều tranh cãi. Việc quyết định điều trị giảm kích thước u trước mổ nên được thực hiện sau khi đã hội chẩn đa chuyên ngành với sự tham gia của phẫu thuật viên, bác sĩ chẩn đoán hình ảnh, bác sĩ hô hấp, bác sĩ ung thư [7].

\subsection{Vấn đề gây mê}

Bệnh nhân có khối u trung thất lớn gây ra những thách thức đáng kể cho gây mê liên quan đến sự cố suy hô hấp và rối loạn huyết động trong 
mổ [2]. Trước khi phẫu thuật cắt bỏ u, cần có một kế hoạch cụ thể giữa phẫu thuật viên và bác sĩ gây mê [8],[9]. Nguy cơ trước phẫu thuật được đánh giá dựa trên lâm sàng, nội soi phế quản và cá dữ liệu chẩn đoán hình ảnh và nhấn mạnh vào các chi tiết khối u, cũng như liên quan với các tổ chức xung quanh. Bệnh sử có thể phát hiện các triệu chứng của đường hô hấp như tím, thở rít, khó thở khi nghỉ ngơi, khó thở tư thế, khó thở khi nằm. Các triệu chứng tim có thể xuất phát từ chèn ép các mạch máu lớn hoặc chèn ép tim. Tất cả các triệu chứng trên cần thiết đánh giá trước phẫu thuật khi bệnh nhân tỉnh táo, đặc biệt khi bệnh nhân nằm ngửa và nằm nghiêng một bên. Hơn nữa tĩnh mạch chủ trên có thể bị xâm lấn bởi khối $\mathrm{u}$, đặt đường tĩnh mạch để hồi sức tốt nhất đặt ở tĩnh mạch đùi. Ngoài ra, việc chuẩn bị đầy đủ huyết áp động mạch, các chế phẩm máu là cần thiết để hồi sức và bù máu khi có rối loạn hô hấp và huyết động xảy ra.

\section{4. Đuờng vào phẫu thuật}

Trong phẫu thuật $\mathrm{u}$ trung thất lớn, đường vào qua mở xương ức, hoặc mở ngực đường bên, trước bên hoặc sau bên (có hoặc không có nội soi hỗ trợ) thường được sử dụng nhất, ít dùng hơn có đường Clamshell cổ điển hoặc hemi - Clamshell tùy theo vị trí, kích thước và sự xâm lấn của khối $\mathrm{u}$ vào các tổ chức xung quanh. Đường mở giữa xương ức cung cấp một phẫu trường lớn hơn với những khối $\mathrm{u}$ trung thất trước khi so sánh với đường mở ngực trước hoặc trước bên. Tiếp cận bằng đường này có thể mở rộng thành đường mở hemi - Clamshell (kết hợp mở dọc xương ức đường giữa một phần và đường mở ngực trước) để nhìn rõ hơn các cấu trúc, đặt biệt phía sau rốn phổi, bao gồm các các thùy phổi và đặc biệt những khối u xâm lấn nhu mô phổi.

\subsection{Phẫu tích khối u}

Đối với các khối u có vỏ, các cấu trúc lân cận thường bị xâm lấn. Nếu tiên lượng khó bóc tách thì có thể bóc $\mathrm{u}$ dưới vỏ để tránh làm tổn thương các tổ chức xung quanh. Đối với các khối $\mathrm{u}$ chèn ép các tạng xung quanh nhưng chưa xâm lấn, nên phẫu tích theo nguyên tắc bảo tổn các cấu trúc để lại, phần u là phần còn lại sau khi phẫu tích. Nếu khối u đã xâm lấn mạch máu, cần cân nhắc cắt bỏ khối u kèm theo mạch bị xâm lấn rồi bắc cầu bằng mạch nhân tạo, miếng vá sinh học còn hơn là cố gắng phẫu tích khối u gây chảy máu khó kiểm soát. Đôi lúc khối u lớn chiếm toàn bộ lồng ngực, không còn phẫu trường để tiếp cần thì đi trực tiếp vào khối $u$, thao tác nhanh để lấy khối u ra khỏi lồng ngưc rồi tiến hành kiểm soát nguồn chảy máu.

\subsection{Xâm lấn tĩnh mạch chủ trên}

Tất cả các khối u liên quan đến trung thất, đặc biệt các khối u lớn đều có khả năng xâm lấn các mạch máu lớn. Tĩnh mạch chủ trên hay bị xâm lấn nhất với mức độ thay đổi từ chèn ép một phần, xâm lấn cho đến phát triển thành hội chứng tĩnh mạch chủ trên [10]. Tỉ lệ xâm lấn tĩnh mạch chủ trên không rõ, do sự hiếm gặp tương đối của bệnh lý này. Một số chùm ca nhỏ đã được báo cáo với sự xuất hiện khoảng $10 \%$ trong hội chứng trung thất. Trong một loạt 89 bệnh nhân với sự xâm lấn nguyên phát khối u trung thất, trải qua phẫu thuật thì $24 \%$ cắt bỏ tĩnh mạch chủ trên [11]. Trong một nghiên cứu đa trung tâm của Ý với 249 bệnh nhân giai đoạn III u tuyến ức, có 12,4\% xâm lấn tĩnh mạch chủ trên [12]. Tùy thuộc vào mức độ xâm lấn, cắt bỏ một phần tĩnh mạch chủ trên có thể thực hiện hoặc thậm chí cắt bỏ toàn bộ và tái tạo lại bằng mạch nhân tạo, miếng vá màng tim hay miếng vá sinh học [10].

Mặc dù cắt bỏ một phần tĩnh mạch chủ trên có thể thực hiện với kẹp một phần tĩnh mạch chủ xuyên suốt quá trình vá lại tĩnh mạch chủ trên, thì việc sử dụng heparin toàn thân nên được sử dụng trước khi kẹp. Tuy nhiên, kẹp tĩnh mạch chủ có thể gây ra rối loạn huyết động nghiêm trọng ở 30\% bệnh nhân và nguy cơ gây tổn thương não [13]. Trong trường hợp này, các thuốc co mạch trong 
phẫu thuật và lượng dịch bù là rất quan trọng trong việc tăng cường máu tĩnh mạch về tim và duy trì áp lực tưới máu não. Vì vậy khi nghi ngờ tĩnh mạch chủ trên bị xâm lấn, nên sử dụng theo dõi đánh giá tưới máu não, tốt nhất theo dõi oxy máu não quang phổ cận hồng ngoại hoặc doppler xuyên sọ, kết hợp với theo dõi áp lực tĩnh mạch cảnh [14].

\section{KẾT LUẬN}

Phẫu thuật điều trị khối u trung thất lớn, cần chú ý đến giải phẫu chi tiết của khối u và quan hệ với các cơ quan xung quanh. Chuẩn bị chi tiết trước phẫu thuật, hội chẩn đa chuyên ngành để lựa chọn điều trị hóa xạ trị trước mổ, các phương pháp gây mê, phẫu thuật là cần thiết cho từng trường hợp cụ thể. Với những kế hoạch chi tiết, đầy đủ sẽ giúp quá trình gây mê và phẫu thuật được thực hiện an toàn.

\section{TÀI LIỆ THAM KHẢO}

1. Duwe B.V., Sterman D.H., and Musani A.I. (2005). Tumors of the Mediastinum. CHEST, 128(4), 2893-2909.

2. Erdös G. and Tzanova I. (2009). Perioperative anaesthetic management of mediastinal mass in adults. Eur J Anaesthesiol, 26(8), 627-632.

3. Takahashi K. and Al-Janabi N.J. (2010). Computed tomography and magnetic resonance imaging of mediastinal tumors. J Magn Reson Imaging JMRI, 32(6), 1325-1339.

4. Biederer J., Mirsadraee S., Beer M., et al. (2012). MRI of the lung (3/3)-current applications and future perspectives. Insights Imaging, 3(4), 373-386.

5. Kesler K.A., Rieger K.M., Hammoud Z.T., et al. (2008). A 25-year single institution experience with surgery for primary mediastinal nonseminomatous germ cell tumors. Ann Thorac Surg, 85(2), 371-378.

6. Koppitz H., Rockstroh J.K., Schüller H., et al. (2012). State-of-the-art classification and multimodality treatment of malignant thymoma. Cancer Treat Rev, 38(5), 540-548.
7. Li W.W.L., van Boven W.J.P., Annema J.T., et al. (2016). Management of large mediastinal masses: surgical and anesthesiological considerations. J Thorac Dis, 8(3), E175-E184.

8. Blank R.S. and de Souza D.G. (2011). Anesthetic management of patients with an anterior mediastinal mass: continuing professional development. Can J Anaesth J Can Anesth, 58(9), 853-859, 860-867.

9. Anderson D.M., Dimitrova G.T., and Awad H. (2011). Patient with posterior mediastinal mass requiring urgent cardiopulmonary bypass. Anesthesiology, 114(6), 1488-1493.

10. Spaggiari L., Leo F., Veronesi G., et al. (2007). Superior vena cava resection for lung and mediastinal malignancies: a single-center experience with 70 cases. Ann Thorac Surg, 83(1), 223-229; discussion 229-230.

\section{Bacha E.A., Chapelier A.R.,} Macchiarini P., et al. (1998). Surgery for invasive primary mediastinal tumors. Ann Thorac Surg, 66(1), 234-239.

12. Dartevelle P.G., Chapelier A.R., Pastorino U., et al. (1991). Long-term follow-up after prosthetic replacement of the superior vena cava combined with resection of mediastinalpulmonary malignant tumors. $J$ Thorac Cardiovasc Surg, 102(2), 259-265.

13. Leo F., Grazia L.D., Tullii M., et al. (2007). Hemodynamic instability during superior vena cava crossclamping: Predictors, management, and clinical consequences. The Journal of Thoracic and Cardiovascular Surgery, 133(4), 1105-1106.

14. Raut M.S., Das S., Sharma R., et al. (2018). Superior Vena Cava Clamping during Thoracic Surgery: Implications for the Anesthesiologist. Ann Card Anaesth, 21(1), 85-87. 